ance of the normal ascorbic acid equilibrium in the plant might contribute to the characteristic symptoms caused by molybdenum deficiency. These views appear consistent with the requirements for molybdenum in the presence of different nitrogen supplies observed described above.

It is hoped to test, and distinguish between, these possibilities by investigations now in progress and to be reported later elsewhere.

Acknowledgment is made to the Agricultural Research Council for providing special apparatus for work on molybdenum deficiency. One of us (E. W. J.) is also indebted to the Council, and another (S. C. A.) to the U.P. Government, India, for providing grants which have enabled them to participate in the work. We also wish to acknowledge the advice of Dr. A. Pollard on the estimation of ascorbic acid in plant extracts.

Long Ashton Research Station,
E. J. HewitT
S. C. Agarwala
E. W. JONES

University of Bristol. July 29.

${ }^{1}$ Hewitt, E. J., and Jones, E. W., J. Pomol. and Hort. Sci., 23, 254 $(1947)$.

${ }^{2}$ Mulder, E. G., Plant and Soil, 1, 94 (1948).

${ }^{3}$ Lemoigne, M., Monguillon, P., and Desvaux, R., C.R. Acad. Sci., Paris, 204, 1841 (1937).

- Virtanen, A. I., Experientia, 8, 313 (1949).

- Virtanen, A. I., and Von Hausen, S. S., Nature, 163, 482 (1949); Z. Pfi. Ernähr., 45, 11 (1949).

6 Jones, W. W. Bitters, W. P., and Finch, A. H., Amer. Soc. Hort. Sci. Proc., 45, 1 (1944).

'Finch, A. H., Jones, W. W., and van Horn, S. W., Amer. Soc. Hort. Sci. Proc., 46, 314 (1947).

${ }^{B}$ Wittwer, S. H., Schroeder, R. A., and Albrecht, W. A., Soil Sci., 59 $329(1945)$.

- Harmer, P. M., and Sherman, G. D., Soil Soc. Amer. Proc., 8, 346 (1943).

${ }^{10}$ Unpublished data.

${ }^{11}$ Crook, E. M., and Morgan, E. G., Biochem. J., 38, 10 (1944).

${ }^{12}$ Waygood, E. R., Canad. J. Res., 28, 7 (1950).

${ }^{13}$ Davison, D. C., Proc. Linn. Soc. N.S. Wales, 74, 26 (1949).

\section{Caudal Ribs in Geckos}

DURING a comparative study of the osteology of some Egyptian geckos, including Stenodactylus stenodactylus, 'T'ropiocolotes tripolitanus, $T$. steudneri, Ptyodactylus hasselquistii, Hemidactylus turcica, Tarentola mauritanica and $T$. annularis, a rather interesting detail concerning the caudal region of the vertebral column was observed, which has not previously been recorded in living Lacertilia, so far as we are aware. It concerns the presence of caudal ribs in geckos. Among the above-mentioned species, such ribs were found in both Tarentola annularis and Ptyodactylus hasselquistii.

As a matter of fact, the caudal vertebræ of Lacertilia are provided with prominent transverse processes, which are particularly well developed in some lizards such as Uromastyx cegyptia ${ }^{1}$. It was found that in both Tarentola annularis and Ptyodactylus hasselquistii the transverse processes of the anterior caudal vertebræ carried at their distal ends small pieces of bone representing caudal ribs. These ribs are clearly articulating with the transverse processes, as seen in skeletons stained with alizarine and cleared according to Hollister's method ${ }^{2}$. They are present on one side of the body only (see accompany. ing illustration). On the opposite side, the lateral process of each rib-bearing vertebra is equal in length to both the transverse process and caudal rib of the $\operatorname{sam} \theta$ vertebra. It is therefore reasonably assumed

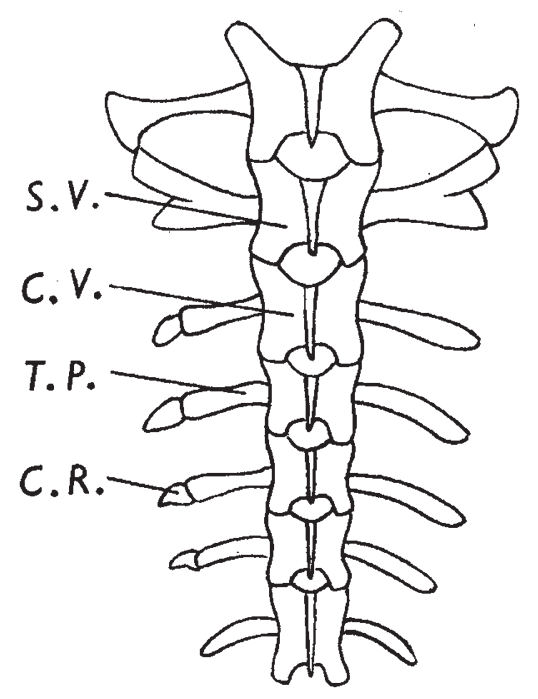

Tarentola annularis. Dorsal view of the two sacral vertebræ and vertebra; S.V., sacral vertebra; T.P., transverse process

that the caudal ribs, which are freely articulating with the transverse processes of one side, are completely fused with the corresponding processes of the opposite side.

In primitive Tetrapoda ribs are present in the different parts of the vertebral column, including not only the cervical, dorsal and sacral, but also the caudal region. Thus Williston ${ }^{3}$ states that in Amphibia and reptiles the ribs "primitively articulate with all vertebræ, at least as far back as the middle of the tail". In the fossil amphibian Eogyrinus the anterior caudal vertebræ are provided with rib facets, as described by Watson 4 . Long and massive caudal ribs, which are quite similar to the dorsals, have been also described by Watson ${ }^{5}$ in the fossil reptile, Seymouria. Thus the well-developed caudal ribs described in fossil Tetrapoda are still retained in the form of a series of rudimentary structures present in the caudal region of some living geckos.

M. R. EL-TouBI

Department of Zoology,

A. KHALIL

Faculty of Science,

Fouad I University, Cairo. Nov. 18.

1 El-Toubi, M. R., J. Morph. (Philadelphia), 84 (1949).

2 Hollister, G., Zoologica (New York), 12 (1934).

Williston, S. W., "The Osteology of Reptiles" (Harvard Univ. Press,
1925).

Watson, D. M. S., Phil. Trans. Roy. Soc., Lond., B, 214 (1926).

${ }^{5}$ Watson, D. M. S., Proc. Zool. Soc., Lond. (1918).

\section{p-Hydroxybenzoic Acid: a New Bacterial Vitamin}

MUtant 83-1 of Escherichia coli, isolated by the penicillin method $x$, is blocked at an early stage in aromatic synthesis; it responds to a quadruple supplement of tyrosine, phenylalanine, tryptophane and $p$-aminobenzoic acid. Whereas the quantitative requirements for the three amino-acids are similar to those of mutants with single requirements for these compounds, growth is very slow with 0.005 $\mu \mathrm{gm} . / \mathrm{ml}$. of $p$-aminobenzoic acid, a concentration sufficient for optimal growth of a mutant blocked 